\title{
Er heilsa metin með hlutfallslegum eða algildum hætti?
}

\author{
Agnar Hafliði Andrésson, hagfræđingur, læknanemi við Háskóla Íslands \\ og Tinna Laufey Ásgeirsdóttir, hagfræđingur, lektor við Hagfræđideild \\ Háskóla Íslands
}

\begin{abstract}
Útdráttur
Fyrri rannsóknir benda til pess að fólki sé minna umhugað um hlutfallslega stöðu heilsu heldur en hlutfallslega stöðu annarra gæða. Heilsa er hins vegar margvíð og aldrei áður hefur verið rannsakað hverjir hlutfallslegir eiginleikar mismunandi vídda heilsu eru. Send var spurningarkönnun á nemendur Háskóla Íslands par sem svarendur voru látnir velja á milli tvenns konar samfélagsástands: í öðru bjuggu peir við betri heilsu en aðrir í samfélaginu, en í hinu bjuggu allir við betri heilsu, en par voru svarendur við lakari heilsu en aðrir. Kannað var með tilgátuprófum hvort ólíkar víddir heilsu væru í mismiklum mæli metnar út frá hlutfallslegri stöðu einstaklings miðað við aðra í samfélaginu. Pá var samband milli lýðfræðilegra- og heilsufarslegra breyta við afstöðu til hlutfallslegrar stöðu mismunandi vídda heilsu metið með logit aðhvarfsgreiningu. Niðurstöður rannsóknarinnar benda til pess að fæstir pættir heilsu hafa ólíka hlutfallslega eiginleika umfram aðra, en einungis líkamspyngd og ungbarnadauði sýndu marktækt frábrugðna eiginleika. Pá virðist heilsa vera almennt talin mjög algild og kýs fólk síður hlutfallslega sterkari stöðu á kostnað algildrar heilsu.
\end{abstract}

Efnisorð: Heilsa; hlutfallsleg staða; lífsgæði.

\author{
Icelandic Review of Politics and Administration Vol. 9, Issue 2 (373-394) \\ (c) 2013 Contact: Tinna Laufey Ásgeirsdóttir, ta@hi.is \\ Article first published online Desember 19th 2013 on http://www.irpa.is \\ Publisher: Institute of Public Administration and Politics, Gimli, Sæmundargötu 1, 101 Reykjavík, Iceland \\ Stjórnmál \& stjórnsýsla 2. tbl., 9. árg. 2013 (373-394) (Fræđigreinar) \\ (c) 2013 Tengiliður: Tinna Laufey Ásgeirsdóttir, ta@hi.is \\ Vefbirting 19. desember 2013 - Birtist á vefnum http://www.irpa.is \\ Útgefandi: Stofnun stjórnsýslufræđa og stjórnmála, Gimli, Sæmundargötu 1, 101 Reykjavík \\ http://dx.doi.org/10.13177/irpa.a.2013.9.2.6 \\ This work is licensed under a Creative Commons Attribution 3.0 License.
}




\section{STJÓRNSÝSLA}

\section{Is health valued in relative or absolute terms? Abstract}

Previous studies indicate that individuals care less about relative health status than relative status of other goods. Health, however, is a multidimensional desideratum and the relative characteristics of different dimensions of health have not been studied before. Respondents to a questionnaire had to choose between two different types of social situations: one, where their health was better than the rest of the society's, and the other, where their health was better than in the previous situation, but everyone else's health was even better than that, so that their relative standing was worse. Hypothesis tests were used to examine to what extent individuals care about different health dimensions based on their relative status compared to others in the society. The relationship between demographic and health status determinants, and the relative status regarding different dimensions of health was examined using logit regression analysis. The results indicate that few dimensions of health have different relative qualities over others, aside from body weight and infant mortality, which were statistically significantly different. In general, health seems to be considered in absolute terms and individuals do not choose relatively stronger health status at the expense of absolute health.

Keywords: Health; relative standing; well being.

\section{Inngangur}

Hlutfallsleg staða skiptir fólk máli í samfélagi par sem samanburður við aðra á sér sífellt stað. Góð hlutfallsleg staða getur veitt virðingu, völd og upplifun af velgengni, ekki síður en magn auðs á hverjum tíma. Nytjar einstaklinga ráðast pví ekki einvörðungu af peim gæðum sem neytt er, heldur einnig af pví magni sem aðrir neyta. Til að mynda má bæði skoða tekjur sem algilda stærð og sem hlutfallslega í samanburði við tekjur fólks í samfélaginu. Mögulegt er að heilsa lúti pessu einnig. Sem dæmi má nefna, að líkamspyngd einstaklings er jafnan mæld algild í kílóum og grömmum en pegar skynjun okkar á holdafari ræðst af pví hversu pungt annað fólk samfélagsins er, mætti álykta að hlutfallsleg pyngd sé einnig mælikvarði sem skiptir máli. Pannig gæti einstaklingur upplifað sig í of pungan í einu samfélagi en ekki í öðru.

Hlutfallsleg staða hefur aðeins að takmörkuðu leyti verið rannsökuð, og pá einna helst kenningalega frekar en með athugunum. Thorstein Veblen (1899) er með peim fyrstu sem tekur á viðfangsefninu pó Adam Smith (1776) hafi áður skrifað um neysluvörur sem væru nauðsynjar vegna peirrar menningarlegu stöðu sem pær höfðu og hversu mikilvæg ákveðin gæði væru fyrir skynjun á stöðu einstaklinga í samfélagi við aðra. Баð var ekki fyrr en mun síðar sem hugmyndin um hlutfallslega stöðu fékk pá skilgreiningu sem notuð er í dag, pað er að nytjar (e. utility) sem fást við neyslu á gæðum ráðist ekki einungis af algildu magni sem neytt er, heldur einnig samanburði við magn sem aðrir neyta af sömu gæðum (Duesenberry 1949, Galbraith 1958, Hirsch 1976).

Samanburður á högum fólks orsakast meðal annars af öfund og getur hún raskað 
hagkvæmni hagkerfis sem jafnvel gæti kallaðá opinbera íhlutun samkvæmt Elster (1991), Frank (1985) og Layard (2011). Einn aðili getur öfundað annan af hluta gæða hans, en án pess að vilja endilega skipta um alla neyslusamsetninguna (Solnick og Hemenway 1998). Frank og Sunstein (2001) benda pó á að öfund purfi ekki að vera ráðandi í hlutfallslegu mati fólks, heldur vegna stöðu annarra sem setur almenn viðmið, par sem efnahagslegog félagsleg umsvif eiga sér stað.

Frank (1985) heldur pví fram að áhyggjur fólks af stöðu eigi ríkjandi pátt í mörgum af mikilvægustu ákvörðunum pess, en hann var síðar fyrstur til að nota hugtakið hlutfallsleg ytri áhrif (Frank 1991). Í nýlegri rannsókn Frank (2008) fjallar hann nánar um hlutfallsleg ytri áhrif og tekur einfalt dæmi um fatnað sem einstaklingar klæðast er peir sækja um vinnu. Gengið er út frá pví að betri og snyrtilegri klæðnaður, sem fólk tekur eftir, auki líkur á pví að vekja hrifningu og par af leiðandi að hljóta starfið. Mæti einn umsækjanda í dýrum, sérsaumuðum jakkafötum pá veldur pað neikvæðum áhrifum á aðra. Fylgja aðrir í kjölfarið kemur upp sú óhagkvæma staða að enginn skarar framúr vegna fatnaðar og allir verða hlutfallslega jafnvel settir og áður, nema að auki hafa peir sóað fjármunum í viðleitni sinni til pess að bæta hlutfallslega stöðu sína. Hann veltir fyrir sér hagkvæmni skattheimtu til að draga úr neikvæðum afleiðingum hlutfallslegra ytri áhrifa, s.s. stighækkandi neyslusköttum par sem lúxusvörur eru óbeint skattlagðar.

Einstaklingar hafa ólíka hlutfallslega afstöðu til mismunandi gæða. Ef öll gæði í nytjafallinu (t.d. frítími jafnt sem tekjur) væru jafn hlutfallsleg pá myndi pað einfaldlega draga úr velferð án pess að breyta hagkvæmri ráðstöfun tíma og peninga, ekki ósvipað eingreiðsluskatti, samkvæmt Arrow o.fl. (2004). Hins vegar benda margar rannsóknir til pess að svo sé ekki. Solnick og Hemenway (1998) eru með peim fyrstu til að spyrja um afstöðu fólks til ólíkrar stöðu í samfélaginu og að kanna tilgátur um hlutfallsleg gæði. Til pess að auka samanburðarmöguleika var litið til peirrar rannsóknar við val rannsóknarsniðins sem notað er í pessari rannsókn. Spurðu pau meðal annars um tekjur, menntun, greind og útlit, ásamt sambærilegum spurningum um börn viðkomandi. Ein tilgáta var sú að sum gæði og eiginleikar væru hlutfallslegri heldur en önnur. Önnur tilgáta var að hlutfallsleg staða birtist ólíkt fyrir gæði og ógæði (e. bads), pannig að fólki sé frekar umhugað um algilda stöðu pegar um ógæði er að ræða, en hallast fremur að hlutfallslegri stöðu í tilfelli gæða. Driðja tilgátan var að hlutfallsleg staða sé sterkari pegar velja á fyrir hönd barna sinna en fyrir sjálfan sig, en almennt er viðurkennt að foreldrar hafa sterka hvöt til pess að veita börnum sínum öll möguleg forskot í lífinu. Helstu niðurstöður hjá Solnick og Hemenway voru pær að um 50 prósent aðspurðra kusu að helminga kaupmátt launa sinna svo lengi sem peir hefðu hlutfallslega há laun. Tilgáturnar sem höfundar settu fram virtust standast, en par kom í ljós að svarendur voru heldur líklegri til pess að svara hlutfallslega pegar börn peirra áttu í hlut, auk pess sem gæði mældust hlutfallslegri en ógæði. Fólk er pannig viljugra að sætta sig við minna af góðum hlut en pað er að sampykkja meira af slæmum hlut til pess að hafa hlutfallslega betri stöðu. Margar fleiri tilgátur um hlutfallslega stöðu hafa verið settar fram, eins og í Carlsson, Johansson-Stenman og Martinsson (2007) sem staðfestu tilgátu sína um að 


\section{STJÓRNSÝSLA}

tekjur séu hlutfallslegri heldur en frítími, en fólk virðist síður viljugt að fórna frítíma til pess að hafa meiri frítíma en aðrir. Einnig lögðu peir til að áberandi gæði, eins og virði bíls, væru hlutfallslegri heldur en dulin gæði, eins og öryggi bíls, og stóðst sú tilgáta einnig. Framansagðar rannsóknir skoða mismunandi hluti, eins og greind viðkomandi og fegurð barna peirra, og bera saman hversu hlutfallslega afstöðu fólk hefur til ólíkra gæða. Við pær greiningar sem hér eru framkvæmdar eru samskonar aðferðir notaðar til аð skoða mismunandi eiginleika heilsu.

Hingað til hafa nytjafræðin byggt á pví að mismunandi vildir (e. preferences) einstaklinga ráða samsetningu nytjafallsins en pað hefur að mestu verið skilgreint út frá algildu sjónarhorni, pó hefur mátt sjá breytingar á pví síðustu árin. Abel (1990) innleiddi í nytjafall hlutfallslega neyslu sem byggði á neyslu einstaklinga í hlutfalli við meðalneyslu og gat með peirri breytingu útskýrt hina svokölluðu áhættuálags gátu (e. equity premium puzzle) sem Mehra og Prescott (1985) settu fram. Nýleg rannsókn Tervala (2012) sýnir að áhrif peningamálastjórnar er háð ytri áhrifum hlutfallslegrar neyslu. Annað rótgróið hugtak sem ekki er auðvelt að samræma við hlutfallslega stöðu er Pareto-bót, sem á við um ráðstöfun verðmæta pannig að enginn verður verr settur en áður en að minnsta kosti einn aðili er betur settur. Hlutfallsleg ytri áhrif valda pví að skilyrði fyrir Pareto-bót eru mun strangari en ef aðeins er horft til algildra breytinga (Hopkins og Kornienko 2009). Yfirlit rannsókna á tengslum hlutfallslegrar stöðu og sjálfmetinnar hamingju má finna í Layard (2011) pó ekki gefist rými hér til pess að fara nákvæmlega í saumana á pví sambandi.

Frank og Sunstein (2001) fundu út að hlutfallslegir eiginleikar eru sterkari pegar greiða parf fyrir gæðin, heldur en pau gæði sem hið opinbera veitir fólki, eins og til dæmis heilbrigðispjónustu, orlof frá vinnu, öryggi á vinnustað og leyfi til að sinna veikum börnum. pessi gæði einkennast af sterkum algildum eiginleikum og pað er mikilvægt að hafa pau, óháð pví hvað aðrir hafa. Velta má fyrir sér hvort pað sama eigi við um heilsu, par sem heilsa fólks er líklegri til að vera góð par sem nægt framboð er af opinberri heilbrigðispjónustu, en pað gæti ýtt undir að heilsa sé almennt algilt gæði. Solnick og Hemenway (2005) rannsökuðu röðun á hlutfallslegum gæðum í nytjafalli einstaklinga. Settu pau meðal annars fram pá tilgátu að neyslugæði líkt og fatnaður og húsnæði séu hlutfallslegri heldur en heilsa og öryggi. Spurt var meðal annars um tekjur, herbergjafjölda í húsnæði, veikindi, lífslíkur og mengun. Niðurstöður voru pær að heilsa og öryggi ráðast fremur af algildum sjónarmiðum en hlutfallslegum og voru neyslugæði almennt hlutfallslegri. Par voru aðeins 11 prósent aðspurðra sem kusu hlutfallslegan kost veikinda frekar en algildan. Samkvæmt pví eru einstaklingar fremur tilbúnir að vera oftar veikir en aðrir, svo framarlega að peir séu ekki mjög oft veikir. Sama útkoma var fyrir lífslíkur í viðkomandi landi, en einstaklingar vilja njóta langlífis jafnvel pó svo aðrir njóti enn meira langlífis. Samanborið við neyslugæði, eins og húsnæði par sem tæpur priðjungur svarenda kaus heldur að hafa fá herbergi í húsnæði sínu svo framarlega að hús nágrannans væri með færri herbergjum, mátti sjá að heilsa virðist vera algildari í huga fólks. एótt að sýnt hafi verið fram á að hlutfallsleg staða heilsu skipti fólk minna máli heldur en flest gæði, pá er heilsa er margvíð og tekur til mismunandi eiginleika, svo sem verkja, hreyfigetu, kvíða og 
getu til að sinna venjubundnum athöfnum. Dví er verðugt að varpa ljósi á hverjir hlutfallslegir eiginleikar mismunandi vídda heilsu eru.

Til að draga saman pá benda rannsóknir til pess að hlutfallsleg neysla hafi raunverulegt vægi í nytjafalli einstaklinga. Pó hafa hlutfallslegir eiginleikar heilsu ekki verið mikið rannsakaðir samanborið við önnur gæði pótt að flest bendi til pess að heilsa sé metin með mjög algildum hætti. Einnig er nú vitað að niðurstöður frá einu landi eru ekki sönnun á afstöðu fólks hvað varðar hlutfallslega stöðu. Svo virðist sem að mikill munur sé á milli svæða í heiminum og benda rannsóknir til pess að menning og próunarstig hafi mikilvæg áhrif á hlutfallslega stöðu (Frey og Stutzer 2002, Solnick, Hong og Hemenway 2007, Clark o.fl. 2008, Knight o.fl. 2009, Caporale o.fl. 2009, Corazzini, Esposito og Majorano 2012, Akay, Martinsson og Medhin 2012). Petta ber að hafa í huga og pví eru niðurstöður hér aðallega bornar saman við birt efni frá Vesturlöndum.

Markmið rannsóknarinnar er prípætt. Í fyrsta lagi, að varpa ljósi pað virði sem fólk leggur á heilsu sína í samanburði við pá heilsufarsstöðu sem almennt gildir í samfélaginu. pessi hluti er í raun endurtekning á pví sem áður hefur verið gert. Hann pjónar bæði peim tilgangi að athuga hvort fyrri rannsóknir séu staðfestar í endurtektarrannsókn og einnig til pess að staðfesta samanburðarhæfi annarra pátta rannsóknarinnar við pað sem áður hefur verið rannsakað. Ef niðurstöður úr pessum hluta rannsóknarinnar væru með mjög ólíkum hætti og pekkst hefur, bæri að gæta sérstakrar varúðar við samanburð á öðrum niðurstöðum pessarar rannsóknar við pað sem áður hefur verið sýnt fram á. Í öðru lagi, að athuga hvort ólíkar víddir heilsu séu í mismiklum mæli metnar út frá hlutfallslegri stöðu einstaklings miðað við aðra í samfélaginu. Eftir pví sem næst verður komist er petta er fyrsta rannsóknin sem kannar pað. Er viðfangsefnið mikilvægt fyrir pær sakir að ólíkir hlutfallslegir eiginleikar gæða geta haft áhrif á hagkvæma skiptingu peirra í gegnum hlutfallsleg ytri áhrif. Pannig getur bætt staða einstaklings valdið pví að aðrir dragist aftur úr frá pví sem áður var og orðið pannig fyrir neikvæðum ytri áhrifum. Er pví mikilvægt að skilja hvernig fólk lítur á mismunandi víddir heilsu út frá hlutfallslegri stöðu við aðra í samfélaginu. Í priðja lagi, að kanna hvaða lýðfræði- og heilsufarslegir eiginleikar tengjast líkum pess að fólk sé tilbúið til pess að fórna algildri heilsu til pess að bæta hlutfallslega heilsu sína. Mikilvægt er að skilja hvaða hópar eru líklegastir til að meta hlutfallslega stöðu til að sjá hvaða einstaklingar verða helst fyrir hlutfallslegum ytri áhrifum.

Niðurstöðurnar sýna að heilsufarslegir pættir eru almennt metnir án tillits til heilsu annarra samfélagspegna. Einnig eru fæstir pættir heilsu aðgreinanlegir hvor frá öðrum er varðar hlutfallslega eiginleika. Ýmsar breytur, bæði lýðfræðilegar og heilsutengdar, eins og aldur, hjúskaparstaða, barneignir og sjálfmetin andleg heilsa, geta útskýrt auknar líkur á að einstaklingar meti hlutfallslega stöðu heilsu mikilvægari en algilda. Niðurstöðurnar styðja pað litla sem rannsakað hefur verið hingað til en hins vegar er enn mikið verk óunnið í pessum nánast ósnerta málaflokki og er brýnt að framkvæma rannsóknir með breytilegum spurningalistum og annars konar úrtaki, og kanna pannig stöðugleika niðurstaðna á milli samfélaga og gagnaöflunarleiða.

Ýmsir fyrirvarar eru settir á rannsóknarformið. Einungis er unnið með fræðilegar 


\section{STJÓRNSÝSLA}

spurningar en ekki er fylgst með raunverulegri hegðun. Gengið er út frá pví að svörun fólks sé rökrétt en sú forsenda er ekki sjálfsögð og geta niðurstöður orðið aðrar við breytingar á formi spurninga. Einnig er hugsanlegt að svörin séu bjöguð að peim viðhorfum og væntingum sem samfélagið krefst af fólki. Til samræmis við fyrri rannsóknir (t.d. Solnick og Hemenway 1998; Alpizar o.fl. 2005; Carlsson o.fl. 2007) var ekki nákvæmlega skilgreint hver viðmiðunarhópurinn væri í spurningunum, en fólk hefur mögulega mismunandi hugmyndir um hann. Pá var spurningalistinn sendur út á nemendur við Háskóla Íslands, en ekki tilviljanakennt úrtak úr Pjóðskrá, en notkun nemenda er algeng á pessu rannsóknarsviði (t.d. Solnick og Hemenway 1998; Johansson-Stenman o.fl. 2002; Alpizar o.fl. 2005).

\section{Efni og aðferðir}

Spurningarlistar voru sendir með tölvupósti á 7446 nemendur Háskóla Íslands, sem gefið höfðu leyfi fyrir pví að taka pátt í könnunum, og 419 svöruðu. Fyrirlögð spurningakönnunin samanstóð af tólf valfrjálsum spurningum sem allar voru settar fram með sama hætti, tvíkosta spurningar, auk spurninga um lýðfræði og bakgrunn. Spurningakönnunin er fáanleg frá höfundum fyrir áhugasama. Hver spurning fól í sér lýsingu á tvenns konar samfélagsástandi og voru pátttakendur beðnir um að velja hvort ástandið peir myndu frekar vilja búa við. Í hvoru ástandi er viðkomandi sagt hvernig eiginleikar heilsu hans eru, og hvernig dæmigerður einstaklingur í samfélaginu er til samanburðar. Kostirnir voru settir upp pannig að annar valkosturinn felur í sér að viðkomandi hefur almennt betri heilsu en aðrir í samfélaginu og er hann skilgreindur sem hlutfallslegt svar. Í hinum kostinum hafa allir pað betra en í hlutfallslega svarmöguleikanum, einnig svarandinn sjálfur, en viðkomandi hefur pað verra heldur en aðrir í samfélaginu og er pað skilgreint sem algilt svar. Dæmi um eina spurningu er (hornklofar voru ekki í könnuninni):

A: Dú ert veik/ur 14 daga á ári - aðrir eru veikir 28 daga á ári [hlutfallslegt svar]

B: Dú ert veik/ur 8 daga á ári - aðrir eru veikir 4 daga á ári [algilt svar]

Valmöguleiki A er hlutfallslega ástandið, par sem viðkomandi er sjaldnar veikur en aðrir, og valmöguleiki B er algilda ástandið, par sem allir eru sjaldnar veikir en í A en viðkomandi er oftar veikur en aðrir í samfélaginu. Sá einstaklingur sem vill hafa pað sem best, jafnvel pó svo aðrir hafi pað enn betra ætti að öllum líkindum að velja ástand B. Ef, hins vegar, hann vill hafa pað hlutfallslega betra en aðrir verður sú tilfinning að vega pyngra en aukin algild gæði og ætti hann pá að velja ástand A. Pótt báðir svarmöguleikar feli í sér hlutfallslegar og algildar stærðir pá verður hér eftir átt við annan valkostinn, par sem lögð er áhersla á hlutfallslega stöðu, sem hlutfallslegt svar og hinn, par sem lögð er áhersla á algilda stöðu, sem algilt svar.

Fólk metur ávinning og tap með mismunandi hætti og er líklegra til að kjósa óbreytt ástand jafnvel pó að um fræðilegar spurningar sé að ræða ('Tversky og Kahneman 1981). Jafnframt virðist fólk líta á fyrri valmöguleikann sem núverandi fræðilegt ástand og hinn 


\section{STJÓRNMÁL \& STJÓRNSÝSLA}

síðari sem breytingu sem pað er beðið um að taka afstöðu til. Solnick og Hemenway (1998) komust að pví að marktækur munur er á niðurstöðum eftir pví hvor valmöguleikinn er á undan. Til að draga úr skekkjuáhrifum á matsstuðla vegna pessa var valmöguleikum spurninga raðað upp handahófskennt fyrir hvern pátttakanda.

Ellefu heilsutengdar spurningar voru lagðar fyrir pátttakendur. Fimm spurningar voru unnar upp úr staðlaða heilsukvarðanum EQ-5D, frá EuroQol Group. Hann mælir fimm víddir heilsu einstaklinga og veitir pannig einfaldan mælikvarða og samanburð á heilsu og er notaður til slíks víða um heim í mörgum rannsóknum á heilsu fólks. Pessar fimm víddir eru hreyfigeta, sjálfsumönnun, venjubundnar athafnir, verkir og punglyndi. Pá var einnig spurt um líkamspyngd, heilsuhreysti, veikindi, lífslíkur, frjósemi og tíðni ungbarnadauða. Allar spurningar voru settar sambærilega fram, í líkingu við dæmið að ofan. Svarendur purftu einnig að taka afstöðu til tekna með einni spurningu, en ástæða pess er sú að í flestum rannsóknum af pessari gerð hefur pað verið gert og pví er gott að hafa pá útkomu til samanburðar og álykta hvort að úrtakið í pessari rannsókn sé frábrugðið öðrum rannsóknum hvað viðhorf til hlutfallslegrar stöðu varðar og til pess að sjá samanburð á milli viðhorfa til heilsu og tekna.

Spurningakönnunin innihélt ellefu kosti fyrir menntun. Við úrvinnslu er menntun skipt upp í fjögur stig: grunnstig, miðstig, hástig og efsta stig. Grunnstig er skilgreint sem grunnskóla-, gagnfræða- eða landspróf. Miðstig er sveinspróf í iðngrein, stútentspróf, tækniskólapróf eða annað próf á framhaldsskólastigi. Hástig er grunnpróf úr háskóla eða meistarapróf í iðngrein. Efsta stig er svo meistara- eða doktorsgráða úr háskóla. Í könnuninni var spurt um fæðingarár en pví var umbreytt í aldur og flokkað eins og fram kemur í Töflu 1, pó bæði samfelld breyta aldurs og strjál flokkabreyta aldurs séu notaðar í rannsókninni.

Fólk var beðið um að meta eigin líkamlegu og andlegu heilsu með fjögurra kosta spurningu. Pá var spurt um hæð og pyngd og út frá pví var reiknaður líkamspyngdarstuðullinn BMI (e. Body Mass Index). Hann er reiknaður með pví að deila pyngd í kílóum með hæð í metrum í öðru veldi $\left(\mathrm{kg} / \mathrm{m}^{2}\right)$. Gagnasafninu var skipt upp í fjóra hópa: peir sem flokkast vannærðir (BMI < 18,5), í kjörpyngd (BMI: 18,5-24,9), í ofpyngd (BMI: 25,0-29,9) og peir sem glíma við offitu (BMI > 30) eins og fram kemur í Töflu 6.

Eins og sést 1 Töflu 1 er úrtakið frekar hneigt að ungum og vel menntuðum námsmönnum sem ekki er hægt að telja til pverskurðar af pjóðfélaginu. Jafnframt eru kynjahlutföllin skökk en ljóst er að hætta er á að úrtakið gefi aðra niðurstöðu en vel dreift og óbjagað úrtak myndi gera. 


\section{STJÓRNSÝSLA}

Tafla 1. Upplýsingar um úrtakið

\begin{tabular}{|c|c|}
\hline \multicolumn{2}{|c|}{$\mathrm{n}=419$} \\
\hline Kyn & \\
\hline Karl & $93(22,2 \%)$ \\
\hline Kona & $316(75,4 \%)$ \\
\hline \multicolumn{2}{|l|}{ Aldur } \\
\hline $18-29$ & $232(55,4 \%)$ \\
\hline $30-39$ & $86(20,5 \%)$ \\
\hline $40-49$ & $55(13,1 \%)$ \\
\hline $50-59$ & $36(8,6 \%)$ \\
\hline $60-69$ & $7(1,7 \%)$ \\
\hline 70 ára og eldri & $3(0,7 \%)$ \\
\hline Međaltal (1.stađalfr) & $32,3(20,6-44,0)$ \\
\hline \multicolumn{2}{|l|}{ Menntun } \\
\hline Grunnstig & $1(0,2 \%)$ \\
\hline Miðstig & $202(48,2 \%)$ \\
\hline Hástig & $141(33,7 \%)$ \\
\hline Efsta stig & $74(17,7 \%)$ \\
\hline \multicolumn{2}{|l|}{ Hjúskaparstaða } \\
\hline Fast samband & $56(13,5 \%)$ \\
\hline Sambúđ & $123(29,6 \%)$ \\
\hline Gift/kvæntur & $112(26,9 \%)$ \\
\hline Fráskilinn & $17(4,1 \%)$ \\
\hline Einhleypur Einhleyp/ur & $120(28,8 \%)$ \\
\hline \multicolumn{2}{|l|}{ Fjöldi barna } \\
\hline 0 & $234(55,8 \%)$ \\
\hline 1 & $49(11,7 \%)$ \\
\hline 2 & $74(17,7 \%)$ \\
\hline 3 & $46(11,0 \%)$ \\
\hline 4 eða fleiri & $16(3,9 \%)$ \\
\hline \multicolumn{2}{|l|}{ Tekjur } \\
\hline 0 - 100 pús & $93(22,8 \%)$ \\
\hline 100-200 pús & $140(34,3 \%)$ \\
\hline 201-300 pús & $72(17,6 \%)$ \\
\hline 301-400 pús & $36(8,8 \%)$ \\
\hline 401-500 pús & $30(7,4 \%)$ \\
\hline 501-600 pús & $17(4,2 \%)$ \\
\hline 600 pús og hærri & $20(4,9 \%)$ \\
\hline \multicolumn{2}{|l|}{ Staða á atvinnumarkaði } \\
\hline Launpegi & $302(72,1 \%)$ \\
\hline Atvinnurekandi eđa einyrki & $43(10,2 \%)$ \\
\hline Námsmađur & $354(84,5 \%)$ \\
\hline Heimavinnandi & $31(7,4 \%)$ \\
\hline Tímabundið frá vinnu & $31(7,4 \%)$ \\
\hline Ellilífeyrispegi eđa öryrki & $9(2,2 \%)$ \\
\hline Atvinnulaus & $16(3,8 \%)$ \\
\hline
\end{tabular}

Birt er lýsandi tölfræði á úrtakinu í Töflu 1 par sem sjá má samsetningu úrtaks og bakgrunn. Til að meta hvort ákveðnir lýðfræðilegir undirhópar eða misjafnlega hraustir einstaklingar hafi svarað með ólíkum hætti var notast við tilgátupróf, eða $t$-próf, ásamt logit aðhvarfsgreiningu og niðurstöðurnar settar fram með gagnlíkindahlutfalli (e. odds ratio) eða hlutfallslíkum (e. odds) í töflum til að einfalda umgjörð og túlkun.

Fyrst eru svör alls hópsins sýnd við spurningum um afstöðu peirra til heilsu í samanburði við heilsu annarra í samfélaginu. Til að meta hvort afstaða til mismunandi pátta heilsu sé tölfræðilega ólík voru framkvæmd tilgátupróf, nánar tiltekið $t$-próf, par sem tilgátan var að hlutfallslegir eiginleikar ólíkra pátta séu hinir sömu og er p-gildi niðurstaðna birt í sér töflu. Баð var mikilvægt til pess að skera úr um pað hvort hægt væri að segja með tölfræðilegri marktækni hvort að mismunandi víddir heilsu hafi ólíka hlutfallslega eiginleika. Niðurstöðurnar sýna p-gildi tilgátuprófs par sem gildi undir 0,05 merkir að breyturnar tvær eru marktækt frábrugðar hvor annarri og tilgátunni er pá hafnað.

Logit aðhvarfsgreiningu var beitt í rannsókninni til pess að meta tengsl skýribreyta við líkur pess að viðkomandi velji hlutfallslegan kost hvers páttar heilsu. Logit líkan Berkson (1951) er aðferð til pess að lýsa sambandi skýribreyta, eins og lýðfræðilegra- eða heilsufarslegra, á tvíkosta (e. binary) útkomu. Kosturinn við Logit líkan er að pegar niðurstöðunni er umbreytt í gagnlíkindahlutfall pá er mjög pægilegt að túlka hana. Gagnlíkindahlutfallið lýsir með einföldum hætti muninum á líkum mismunandi undirflokka á að velja hlutfallslega valmöguleikann. Einfaldleik- 


\section{STJÓRNMÁL \& \\ STJÓRNSÝSLA}

anum fylgja líka takmarkanir gagnlíkindahlutfallsins, par sem mikilvægar upplýsingar geta tapast ef reynt er að skýra breytu sem í eðli sínu er samfelld, með tvíkosta umbreytingu, eins og að skipta pátttakendum í tvo hópa eftir aldri. Afleiðingarnar geta verið pær að sannarlegt samband tapast eða sýnt er fram á tengsl sem ekki fást staðist. Til að taka á pessum takmörkunum gagnlíkindahlutfallsins voru að lágmarki tvö viðmið par sem breytan tekur einingargildi svo unnt væri að bera saman tengslin. Í öllum logit líkönum rannsóknarinnar tók hlutfallslegi valmöguleiki háðu breytunnar gildið einn og algildi valmöguleikinn gildið núll. Af pví leiðir að öll gagnlíkindahlutföll sýna muninn á líkum undirflokka á velja hlutfallslega valmöguleikann.

Logit aðhvarfsgreining var framkvæmd með tveimur ólíkum nálgunum. Hin fyrri var framkvæmd með einni skýribreytu, án pess að leiðrétta fyrir öðrum páttum. Par voru könnuð tengsl stakra lýðfræðilegra skýristærða við ólíka pætti heilsu. Kannað var hvort að svörun væri ólík eftir kyni, aldri, menntun, tekjum, barneignum, hjúskap eða atvinnu. Síðari nálgunin var gerð með mörgun skýribreytum par sem tengsl margra lýðfræðilegra skýristærða voru metin við pætti heilsu samtímis. Gallinn við að leiðrétta ekki fyrir öðrum páttum er að mögulega gæti breytan virst ranglega skýra einhver tengsl á meðan raunin gæti verið sú að önnur undirliggjandi breyta, raskandi páttur (e. confounder), sem er bæði tengd skýribreytunni og háðu breytunni og lýsir hinum sönnu tengslum við háðu breytuna skekkir myndina. Fjölbreytu logit aðhvarfsgreining var pví notuð til pess að leiðrétta fyrir raskandi páttum. Sumar lýðfræðilegar breytur voru prófaðar oft á mismunandi formi. Pannig voru áhrif aldurs metin bæði með samfelldri breytu og einnig með tveimur strjálum breytum, par sem annars vegar voru skoðuð tengsl peirra sem eru undir prítugu og hins vegar undir fertugu við líkur pess að velja hlutfallslega heilsu. Đá voru tvær skýribreytur af tekjum, par sem annars vegar voru skoðað tengsl peirra sem hafa tekjur undir 200 púsund krónum á mánuði og hins vegar undir 300 púsundum, við líkur pess að velja hlutfallslegt svar.

Heilsa einstaklinga getur mögulega haft áhrif á hvernig heilsutengdum spurningum er svarað og voru pví könnuð tengsl sjálfmetinnar heilsu og líkamspyngdarstuðulsins BMI við líkur pess að velja hlutfallslega kostinn. Með pví var athugað hvort afstaða mis heilsuhraustra hópa væri ólík til hlutfallslegra eiginleika heilsu. Tvær aðferðir, sambærilegar peim sem fyrr hafa verið nefndar, voru notaðar. Annars vegar einnar skýribreytu líkan og hins vegar útvíkkað fjölbreytulíkan, par sem premur skýribreytum hafði verið bætt við: sjálfmetnu stærðirnar líkamleg- og andleg heilsa og svo BMI stuðull viðkomandi sem er á samfelldu formi. Úrtakinu var skipt upp í tvo hópa, peir sem sögðust annars vegar vera með mjög góða eða góða líkamlega eða andlega heilsu og hins vegar peir sem kváðust vera með sæmilega eða lélega heilsu. Niðurstöðurnar eru birtar sem gagnlíkindahlutfall og hlutfallslíkur, eftir pví sem viðá. Pá var að lokum athugað hver tengsl ólíkra BMI pyngdarflokka við líkur pess að velja hlutfallslegan valkost líkamspyngdar. Par eru peir hópar sem ekki teljast of feitir, p.e. vannærðir, í kjörpyngd, í ofpyngd, miðaðir við offituhópinn. Byrjað var á einföldu einnar breytu líkani sem var svo útvíkkað í tveimur skrefum og fleiri skýribreytur teknar inn í. 


\section{STJÓRNSÝSLA}

\section{Niðurstöður}

Almennt séð var afstaða fólks til heilsu mjög algild, eins og sést í Töflu 2. Par má sjá að í nær öllum spurningum kaus yfirgnæfandi meirihluti algilda valmöguleikann, en hlutfall peirra sem valdi hlutfallslega kostinn var á bilinu 4,1 til 12,9 prósent.

Tafla 2. Lýsandi tölfræđi um hlutfallslega eiginleika heilsu

\begin{tabular}{lrr}
\hline & Hlutfallslegt (\%) & Algilt (\%) \\
\hline Tekjur & 44,9 & 54,7 \\
EQ-5D flokkun heilsu & & \\
Hreyfigeta & 5,0 & 94,5 \\
Sjálfsumönnun & 7,4 & 91,4 \\
Venjubundnar athafnir & 8,1 & 91,2 \\
Verkir/ópægindi & 4,5 & 94,0 \\
Kvíði/dapurleiki/punglyndi & 4,1 & 94,7 \\
Ađrir eiginleikar heilsu & & \\
Pyngd & 12,4 & 87,1 \\
Veikindi & 6,2 & 92,6 \\
Lífslíkur & 5,0 & 94,5 \\
Frjósemi & 5,0 & 94,3 \\
Ungbarnadauđi & 12,9 & 85,9 \\
\hline
\end{tabular}

Spurningin um tekjur skipti svarendum í tvo nokkuð jafna hópa, eins og sést í Töflu 2, en tæpur helmingur kaus fremur að búa í samfélagi par sem peir hafa helmingi minni kaupmátt svo lengi sem tekjur peirra eru tvöfalt hærri en tekjur annarra. Mikill munur var á svörun milli kynja, en stærra hlutfall kvenna en karla valdi hlutfallslega háar tekjur (49\% gegn 34\%). Gagnlíkindahlutfallið fyrir kyn sem skýribreytu er 1,81 ( $p=0,016)$ fyrir konur, sem að öðru óbreyttu má túlka pannig að næstum tvöfalt meiri líkur séu á (+81\%) að pær velji hlutfallslega kostinn heldur en karlar. Degar tekjur voru metnar út frá stærra líkani og leiðrétt fyrir fleiri páttum, peim sömu og í Töflu 5, var niðurstaðan hin sama, aðeins kyn hafði marktæk tengsl með gagnlíkindahlutfall upp á 1,79 ( $p=0,023)$. Mismunandi ráðstöfunartekjur svarenda höfðu engin áhrif á pessa svörun, né aðrir lýðfræðilegir eiginleikar.

Afstaða fólks til mismunandi vídda heilsu var svipuð að pví leyti að pað kaus síður hlutfallslega möguleikann á kostnað algildrar heilsu. Fáir pættir heilsu voru marktækt frábrugðnir öðrum ( $>>0,05)$, samkvæmt hefðbundnu $t$-prófi, eins og sést í Töflu 3. Hins vegar má sjá að pyngd og ungbarnadauði voru pær stærðir sem mældust marktækt hlutfallslegri en aðrir eiginleikar heilsu $(\mathrm{p}<0,05)$. Staðlaði heilsukvarðinn EQ-5D, sem mælir fimm ólíkar víddir heilsu, var með svarhlutfall á bilinu 4,1 til 8,1 prósent fyrir hlutfallslega valmöguleikann, par sem venjubundnar athafnir komu út mest hlutfallslegar en 
kvíði, dapurleiki og punglyndi par síst. Ekki er hægt að fullyrða að nokkur af pessum fimm víddum heilsu sé með ólíka hlutfallslega eiginleika umfram aðrar.

Tafla 3. t-próf á breytum (p-gildi)

\begin{tabular}{|c|c|c|c|c|c|c|c|c|c|c|}
\hline & $\begin{array}{l}\text { Hreyfi- } \\
\text { geta }\end{array}$ & $\begin{array}{l}\text { Sjálfs- } \\
\text { umön. }\end{array}$ & $\begin{array}{l}\text { Venjub. } \\
\text { athafn. }\end{array}$ & $\begin{array}{l}\text { Verkir/ } \\
\text { ópæg. }\end{array}$ & $\begin{array}{l}\text { Kvíđi/ } \\
\text { pungl. }\end{array}$ & Pyngd & Veikindi & Lífslíkur & $\begin{array}{l}\text { Frjó- } \\
\text { semi }\end{array}$ & $\begin{array}{l}\text { Ungb.- } \\
\text { dauði }\end{array}$ \\
\hline Hreyfigeta & - & 0,303 & 0,197 & 0,837 & 0,651 & $0,006 * *$ & 0,585 & 0,999 & 0,996 & $0,004 * *$ \\
\hline Sjálfsumönnun & 0,303 & - & 0,796 & 0,217 & 0,139 & 0,089 & 0,629 & 0,303 & 0,305 & 0,061 \\
\hline Venjub. athafnir & 0,197 & 0,796 & - & 0,135 & 0,082 & 0,149 & 0,458 & 0,197 & 0,199 & 0,107 \\
\hline Verkir/ópægindi & 0,837 & 0,217 & 0,135 & - & 0,806 & $0,003 * *$ & 0,453 & 0,837 & 0,832 & $0,002^{* *}$ \\
\hline Kvíði/dapurl./pungl. & 0,651 & 0,139 & 0,082 & 0,806 & - & $0,001 * *$ & 0,319 & 0,651 & 0,647 & $0,001 * *$ \\
\hline Pyngd & $0,006 * *$ & 0,089 & 0,149 & $0,003^{* *}$ & $0,001 * *$ & - & $0,029 *$ & $0,006 * *$ & $0,006 * *$ & 0,862 \\
\hline Veikindi & 0,585 & 0,629 & 0,458 & 0,453 & 0,319 & $0,029 *$ & - & 0,585 & 0,588 & $0,019 *$ \\
\hline Lífslíkur & 0,999 & 0,303 & 0,197 & 0,837 & 0,651 & $0,006 * *$ & 0,585 & - & 0,996 & $0,004 * *$ \\
\hline Frjósemi & 0,996 & 0,305 & 0,199 & 0,832 & 0,647 & $0,006^{* *}$ & 0,588 & 0,996 & - & $0,004 * *$ \\
\hline Ungbarnadauði & $0,004 * *$ & 0,061 & 0,107 & $0,002 * *$ & $0,001 * *$ & 0,862 & $0,019 *$ & $0,004 * *$ & $0,004 * *$ & - \\
\hline
\end{tabular}

${ }^{*} \mathrm{p}<0,05 ; * * \mathrm{P}<0,01 ; * * * \mathrm{P}<0,001$

Fáar lýðfræðilegar breytur sýndu marktækar líkur á að einstaklingar velji hlutfallslega valmöguleikann frekar en pann algilda, hvort sem skoðað var út frá einnar breytu líkani eða fjölbreytu líkani, eins og sjá má í Töflu 4 og Töflu 5. Af ólíkum víddum heilsu úr EQ-5D voru aldur og barneignir einu breyturnar sem uppfylltu kröfu um marktækni. Par sem aldur er samfelld breyta er niðurstaðan á formi hlutfallslíkinda (e. odds). Sýnir hún auknar líkur á að velja hlutfallslegan valmöguleika hreyfigetu; verkja og ópæginda; og kvíða, dapurleika og punglyndis par sem hlutfallslíkur á að velja hlutfallslega kostinn jukust með hverju aldursári um 1,032-1,038 samkvæmt einnar breytu líkaninu í Töflu 4. Pegar leiðrétt var fyrir fleiri breytum í fjölbreytu líkaninu töpuðu sumar breytur marktækni, nema í tilfelli verkja og ópæginda með hlutfallslíkum upp á 1,052 fyrir hvert aldursár. Barnlaust fólk svaraði í mun meiri mæli hlutfallslega um venjubundnar athafnir, með gagnlíkindahlutfall upp á 3,93 samkvæmt fjölbreytu líkaninu í Töflu 5. Par komst kynferði og aldur nálægt marktækni í venjubundnum athöfnum með gagnlíkindahlutfall upp á 3,17 (p = 0,069) fyrir konur og hlutfallslíkur upp á 1,035 ( $p=0,066)$ fyrir hvert aldursár. Engir aðrir lýðfræðilegir eiginleikar höfðu marktæk áhrif á líkur pess að svara pessum fimm ólíku víddum heilsu hlutfallslega. 


\section{STJÓRNSÝSLA}

Tafla 4. Einnar breytu logit aðhvarfsgreining

\begin{tabular}{|c|c|c|c|c|c|c|c|c|c|c|}
\hline & $\begin{array}{l}\text { Hreyfi- } \\
\text { geta }\end{array}$ & $\begin{array}{l}\text { Sjálfs- } \\
\text { umön. }\end{array}$ & $\begin{array}{l}\text { Venjub. } \\
\text { athafn. }\end{array}$ & $\begin{array}{l}\text { Verkir/ } \\
\text { ópæg. }\end{array}$ & $\begin{array}{l}\text { Kvíđi/ } \\
\text { pungl. }\end{array}$ & Pyngd & Veikindi & Lífslíkur & $\begin{array}{l}\text { Frjó- } \\
\text { semi }\end{array}$ & $\begin{array}{l}\text { Ungb.- } \\
\text { dauđi }\end{array}$ \\
\hline Kyna & 0,67 & 1,47 & 3,06 & 2,21 & 4,21 & 1,24 & 0,61 & 1,72 & 1,70 & 1,00 \\
\hline Aldur ${ }^{b}$ & $1,032^{*}$ & 1,077 & 1,101 & $1,038^{*}$ & $1,038^{*}$ & $0,956 * *$ & 1,012 & 0,978 & 0,998 & 1,017 \\
\hline Aldur $30^{c}$ & 0,72 & 1,15 & 1,54 & 0,72 & 0,71 & $3,45^{* * *}$ & 1,10 & 1,33 & 1,07 & 0,78 \\
\hline Aldur $40^{c}$ & 0,50 & 0,77 & 1,04 & 0,42 & 0,43 & 1,56 & 0,84 & 1,96 & 1,35 & 0,81 \\
\hline Tekjur $200^{d}$ & 1,22 & 1,62 & 1,42 & 1,04 & 1,08 & $2,17^{*}$ & 0,73 & 1,00 & 0,99 & 1,02 \\
\hline Tekjur $300^{d}$ & 0,83 & 1,43 & 1,63 & 1,27 & 1,09 & 1,66 & 0,74 & 1,08 & 1,08 & 0,86 \\
\hline Barneignire & 0,85 & 1,25 & 2,01 & 1,10 & 0,69 & $2,13^{*}$ & 1,07 & 1,60 & 1,29 & 0,91 \\
\hline Menntun ${ }^{f}$ & 0,97 & 1,31 & 1,41 & 0,61 & 0,44 & 1,54 & 1,07 & 2,12 & 0,78 & 1,19 \\
\hline Hjúskaparstađag & 0,99 & 1,18 & 0,87 & 1,16 & 0,51 & 0,79 & 0,91 & 0,98 & 1,55 & 1,15 \\
\hline Námsmađur ${ }^{\mathrm{h}}$ & 0,74 & 1,77 & 1,40 & 0,98 & 1,39 & 1,45 & - & 0,76 & 1,77 & 0,78 \\
\hline
\end{tabular}

Hver reitur er eitt líkan.

a dummy breyta fyrir kyn; kvk $=1, \mathrm{kk}=0$.

${ }^{\mathrm{b}}$ samfelld skýribreyta. Sýnir hvað aukning um eina einingu veldur mikilli breytingu í prósentum á að velja hlutfallslega

kostinn.

c dummy breyta fyrir aldur undir 30 og 40 ára.

d dummy breyta fyrir tekjur undir 200 pús. og 300 pús.

${ }^{c}$ dummy breyta fyrir börn; barnlausir $=1$, aðrir $=0$.

${ }^{\mathrm{f}}$ dummy breyta fyrir menntun; grunn- og framhaldsskólamenntun $=1$, háskólamenntun og hærra $=0$.

${ }^{\mathrm{g}}$ dummy breyta fyrir hjúskaparstöðu; einhleypir $=1$, aðrir $=0$.

${ }^{\mathrm{h}}$ dummy breyta fyrir námsmenn; námsmaður $=1$, aðrir $=0$.

- : útkomu sleppt vegna of fárra gilda.

${ }^{*} \mathrm{p}<0,05 ; * * \mathrm{P}<0,01 ; * * * \mathrm{P}<0,001$

Tafla 5. Fjölbreytu logit aðhvarfsgreining

\begin{tabular}{|c|c|c|c|c|c|c|c|c|c|c|}
\hline & $\begin{array}{l}\text { Hreyfi- } \\
\text { geta }\end{array}$ & $\begin{array}{l}\text { Sjálfs- } \\
\text { umön. }\end{array}$ & $\begin{array}{l}\text { Venjub. } \\
\text { athafn. }\end{array}$ & $\begin{array}{l}\text { Verkir/ } \\
\text { ópæg. }\end{array}$ & $\begin{array}{l}\text { Kvíđi/ } \\
\text { pungl. }\end{array}$ & Pyngd & Veikindi & Lífslíkur & $\begin{array}{l}\text { Frjó- } \\
\text { semi }\end{array}$ & $\begin{array}{l}\text { Ungb.- } \\
\text { dauđ̃i }\end{array}$ \\
\hline Kyna & 0,54 & 1,41 & 3,17 & 2,12 & 3,21 & 1,12 & 0,64 & 1,86 & 2,08 & 1,01 \\
\hline Aldurb & 1,040 & 1,021 & 1,035 & $1,052^{*}$ & 1,034 & 0,968 & 1,009 & 0,994 & 1,008 & 1,024 \\
\hline Tekjur 200d & 2,14 & 2,05 & 1,24 & 1,68 & 1,77 & 1,38 & 0,64 & 0,578 & 1,01 & 1,27 \\
\hline Barneignire & 1,03 & 1,09 & $3,93 * *$ & 2,50 & 1,58 & 1,75 & 1,24 & 1,61 & 1,50 & 0,94 \\
\hline Menntunf & 1,06 & 1,00 & 1,22 & 0,49 & 0,36 & 0,95 & 1,08 & 2,42 & 0,60 & 1,40 \\
\hline Hjúskaparstađag & 0,85 & 1,16 & 0,59 & 1,24 & 0,50 & $0,45^{*}$ & 0,75 & 0,63 & 1,73 & 1,13 \\
\hline Námsmađurh & 0,89 & 2,06 & 2,19 & 2,90 & - & 1,48 & - & 1,23 & 3,69 & 0,78 \\
\hline
\end{tabular}

Hver dálkur er eitt líkan.

Đær spurningar sem oftast var svarað á hlutfallslegan máta vörðuðu ungbarnadauða og pyngd. Ungbarnadauði í viðkomandi landi er óbeinn mælikvarði á heilsu, par sem heilsa og lífsstíll móður ásamt heilsufarslegu umhverfi samfélags, getur haft áhrif á tíðni ungbarnadauða, en lýsir jafnframt samfélagslegu ógæði sem er gjarnan notað til að bera saman gæði heilbrigðiskerfa á milli landa (World Health Organization 2005). Peirri spurningu var næst oftast svarað á algildan máta, en um tæplega 13 prósent kusu hærri 
tíðni ungbarnadauða í sínu landi til pess að hafa hlutfallslega betri stöðu en önnur lönd. Flestir vildu fremur hafa lægri tíðni ungbarnadauða jafnvel pótt svo önnur lönd hefðu helmingi minni ungbarnadauða. Engar lýðfræðilegar breytur gátu útskýrt auknar líkur á að velja hlutfallslega valmöguleikann, samkvæmt logit líkani, en gagnlíkindahlutfallið vék sjaldnast langt frá 1,0 .

Ríflega 12 prósent svarenda kaus fremur að vera meira yfir kjörpyngd svo framarlega sem aðrir væru enn meira yfir kjörpyngd, semsagt í minni byngd en aðrir í samfélaginu. Aldur, hjúskaparstaða og barneignir virtust hafa áhrif á líkur pess að velja hlutfallslega kostinn. Aldur hafði afgerandi tengsl ef horft er til einnar breytu líkansins í Töflu 4 með hlutfallslíkur upp á 0,956 sem pýðir að við hækkandi aldur minnkuðu líkur pess að velja hlutfallslega valmöguleikann. Pegar bornir voru saman svarendur yngri og eldri en prítugt fékkst gagnlíkindahlutfall sem nam 3,45 en lækkaði verulega og varð ómarktækt pegar fertugir voru viðmiðið. Í útvíkkaða líkaninu í Töflu 5 var stuðullinn fyrir aldur ekki marktækur, en gildið á honum breyttist lítið og nam hann 0,968 ( $p=0,168)$. Pá voru einhleypir pátttakendur mun ólíklegri en aðrir til pess að velja hlutfallslegan valmöguleika líkamspyngdar, með gagnlíkindahlutfall upp á 0,45. Tekjulágir og barnlausir virtust mun líklegri til pess að velja hlutfallslega valmöguleika líkamspyngdar samkvæmt einnar breytu líkaninu, en hlutföllin bæði lækkuðu verulega og misstu marktækni pegar líkanið var útvíkkað með mörgum breytum, pótt barnlausir hafi ekki verið langt frá marktækni. Aðrir lýðfræðilegir eiginleikar höfðu ekki áhrif.

Lítil eða ómarktæk tengsl voru á milli annarra vídda heilsu og lýðfræðilegra eiginleika. Menntunarstig og námsmenn höfðu engin tengsl við neina pætti heilsu. Нvað einstaklinga sem ekki voru í námi varðar pá voru of fáir eða engir sem svöruðu hlutfallslega kostinum í spurningunum um veikindi og kvíða, dapurleika og punglyndi og varð gagnlíkindahlutfallið óendanlega hátt með engri marktækni og útkomunni pví sleppt úr Töflu 4 og Töflu 5.

Tafla 6. Sjálfmetin heilsa úrtaks

\begin{tabular}{lc|lc}
\hline \multicolumn{2}{c}{ Hlutfall (\%) } & Hlutfall (\%) \\
\hline Líkamleg heilsa & & Andleg heilsa & \\
Mjög góð & 36,8 & Mjög góð & 41,3 \\
Gód & 46,8 & Góð & 43,7 \\
Sæmileg & 13,5 & Sæmileg & 13,1 \\
Léleg & 2,4 & Léleg & 1,9 \\
\hline
\end{tabular}

Líkamspyngdarstuðull (BMI)

\begin{tabular}{lclc}
\hline Međaltal & 25,2 & Vannærðir & 3,6 \\
Miðgildi & 24,2 & Kjörpyngd & 52,5 \\
Stađalfrávik & 5,2 & Ofpyngd & 28,2 \\
Svarbil & $16,2-58,8$ & Offita & 13,1 \\
\hline
\end{tabular}




\section{STJÓRNSÝSLA}

Tafla 7. Einnar breytu logit ađhvarfsgreining - sjálfmetin heilsa og BMI

\begin{tabular}{|c|c|c|c|c|c|c|c|c|c|c|}
\hline & $\begin{array}{r}\text { Hreyfi- } \\
\text { geta } \\
\end{array}$ & $\begin{array}{l}\text { Sjálfs- } \\
\text { umön. }\end{array}$ & $\begin{array}{l}\text { Venjub. } \\
\text { athafn. }\end{array}$ & $\begin{array}{c}\text { Verkir/ } \\
\text { ópæg. }\end{array}$ & $\begin{array}{l}\text { Kvídi/ } \\
\text { pungl. }\end{array}$ & Pyngd & Veikindi & Lífslíkur & $\begin{array}{l}\text { Frjó- } \\
\text { semi }\end{array}$ & $\begin{array}{l}\text { Ungb.- } \\
\text { dauđ̃i }\end{array}$ \\
\hline Líkamleg heilsa & 0,60 & 1,01 & 1,13 & 0,69 & 0,62 & 2,52 & 1,50 & 0,81 & 0,80 & 0,93 \\
\hline Andleg heilsa ${ }^{b}$ & 1,07 & 1,20 & 0,80 & 0,48 & 2,96 & 1,14 & 0,55 & 0,74 & $0,25 * *$ & 1,01 \\
\hline $\mathrm{BMI}^{\mathrm{C}}$ & 0,996 & 0,953 & 0,974 & 0,962 & 0,922 & 0,945 & 1,031 & 0,948 & 0,948 & 1,034 \\
\hline
\end{tabular}

Hver reitur er eitt líkan.

${ }^{a}$ Dummy breyta fyrir líkamlega heilsu; mjög góð eða góð $=1$, sæmileg eða léleg $=0$.

${ }^{\mathrm{b}}$ Dummy breyta fyrir andlega heilsu; mjög góð eða góð $=1$, sæmileg eða léleg $=0$.

${ }^{\mathrm{C}}$ samelld skýribreyta.

- : útkomu sleppt vegna of fárra gilda.

${ }^{*} \mathrm{p}<0,05 ; * * \mathrm{P}<0,01 ; * * * \mathrm{P}<0,001$

Tafla 8. Útvíkkað fjölbreytulíkan - sjálfmetin heilsa og BMI

\begin{tabular}{lllllllllll}
\hline & $\begin{array}{l}\text { Hreyfi- } \\
\text { geta }\end{array}$ & $\begin{array}{l}\text { Sjálfs- } \\
\text { umön. }\end{array}$ & $\begin{array}{l}\text { Venjub. } \\
\text { athafn. }\end{array}$ & $\begin{array}{l}\text { ópkær. } \\
\text { óp. }\end{array}$ & $\begin{array}{l}\text { Kvíđi/ } \\
\text { pungl. }\end{array}$ & pyngd & Veikindi & Líflíkur & $\begin{array}{l}\text { Frjó- } \\
\text { semi }\end{array}$ & $\begin{array}{l}\text { Ungb.- } \\
\text { dauđi }\end{array}$ \\
\cline { 2 - 11 } Líkamleg heilsaa & 0,63 & 1,01 & 2,13 & 1,53 & 0,45 & $4,55^{*}$ & 2,65 & 1,62 & 2,34 & 1,25 \\
Andleg heilsab & 1,09 & 0,99 & 0,71 & 0,41 & - & 0,77 & 0,37 & 0,74 & $0,25 *$ & 0,89 \\
BMlc & 0,980 & 0,960 & 1,003 & 0,965 & 0,909 & 0,983 & 1,048 & 0,968 & 0,948 & 1,035 \\
\hline
\end{tabular}

Útvíkkað frá sömu breytum og í Töflu 5.

Niðurstöður á sjálfmetinni heilsu pátttakenda sjást í Töflu 6. Fólk getur haft ólíka afstöðu til hlutfallslegrar heilsu eftir pví hvernig pað metur heilsu sína, hvort sem um er að ræða andlega eða líkamlega heilsu. Góð eða mjög góð sjálfmetin líkamleg heilsa hafði jákvæð tengsl við að velja hlutfallslegan kost líkamspyngdar, með gagnlíkindahlutfall upp á 4,55 samkvæmt útvíkkaða líkaninu í Töflu 8. Í einnar breytu líkaninu sýndi pað ekki eins sterk tengsl, né náði marktækni, en hlutfallið var 2,52 ( $\mathrm{p}=0,082)$, eins og sést í Töflu 7. Samkvæmt pví var líklegra að einstaklingar, sem meta heilsu sína góða eða mjög góða, hafi fremur kosið að vera meira yfir kjörpyngd svo lengi sem aðrir væru pyngri, heldur en að vera nær kjörpyngd par sem aðrir væru grennri. Sjálfmetin andleg heilsa hafði mjög sterk neikvæð tengsl við að velja hlutfallslegan valkost frjósemi. Afstaða einstaklinga sem mátu sig með mjög góða eða góða andlega heilsu var með peim hætti að peir kusu síður hlutfallslega mikla frjósemi á kostnað algildrar heilsu. Gagnlíkindahlutfallið nam 0,25 hvort sem litið var á einnar breytu líkanið eða pað útvíkkaða, sem pýðir að líkurnar á að peir, sem mátu andlega heilsu sína mjög góða eða góða, hafi valið hlutfallslegan kost frjósemi voru aðeins fjórðungur af líkum peirra sem mátu heilsu sína sem sæmilega eða lélega á að velja pann kost. Mjög góð eða góð andleg heilsa gæti líka haft neikvæð tengsl við líkur pess að velja hlutfallslega kost veikinda, með gagnlíkindahlutfall upp á 0,37 (p = 0,086), sem uppfyllti pó ekki hefðbundna kröfu um marktækni. Tengsl líkamlegrar og andlegrar heilsu við afstöðu fólks til hlutfallslegrar heilsu virtist stangast á ef litið er á niðurstöðurnar í Töflu 8. Par sést að flestir stuðlar líkamlegar heilsu voru stærri en einn, sem pýðir að heilsuhraustir voru líklegri að velja hlutfallslega kostinn, á meðan stuðlar 
andlegrar heilsu voru flestir vel undir einum, sem pýðir að góð andleg heilsa dró úr líkum á að velja hlutfallslega kostinn.

Tafla 9. Tengsl BMI við afstöðu til hlutfallslegrar pyngdar

\begin{tabular}{lccc}
\hline Líkan 1 $^{\mathbf{a}}$ & Stuðull & $\mathbf{p}$ & OR \\
\hline Vannærðir & 1,98 & 0,041 & 7,23 \\
Kjörpyngd & 1,48 & 0,048 & 4,37 \\
Yfirpyngd & 1,27 & 0,110 & 3,57 \\
\hline Líkan 2 $^{\text {b }}$ & & & \\
\hline Vannærðir & 1,68 & 0,089 & 5,42 \\
Kjörpyngd & 1,17 & 0,123 & 3,23 \\
Yfirpyngd & 1,03 & 0,187 & 2,81 \\
\hline Líkan 3 & & & \\
\hline Vannærðir & 1,46 & 0,159 & 4,29 \\
Kjörpyngd & 0,91 & 0,242 & 2,49 \\
Yfirpyngd & 0,86 & 0,285 & 2,36 \\
\hline
\end{tabular}

a engar aðrar skýribreytur.

${ }^{\mathrm{b}}$ leiðrétt fyrir kyni og aldri.

c útvíkkað frá sömu breytum og í Töflu 5.

Líkamspyngdarstuðull, BMI, á formi samfelldrar breytu náði ekki að útskýra, svo marktækt sé, ákveðna afstöðu til hlutfallslegrar stöðu heilsu, eins og sjá má í Töflu 7 og Töflu 8. Í tilfelli líkamspyngdar í einnar breytu líkaninu var BMI nálægt marktækni par sem hlutfallslíkur námu 0,945 ( $\mathrm{p}=$ 0,098), en hlutfallið færðist nær einum og tapaði marktækni í útvíkkaða líkaninu. Til að skoða afstöðu fólks í ólíkum pyngdarflokkum BMI til hlutfallslegrar pyngdar, var einstaklingum skipt upp eftir fjórum BMI flokkum: vannærðir - kjörpyngd - yfirpyngd - offita. Hlutfall peirra sem svöruðu líkamspyngd hlutfallslega lækkaði eftir pví sem líkamspyngdarstuðullinn varð hærri (21\% - 14\% - 12\% - 4\%). Tafla 9 sýnir niðurstöðurnar par sem fyrstu prír hóparnir eru bornir saman við pyngsta hópinn, offitu. Par má sjá stighækkandi líkur á pví að velja hlutfallslega kostinn eftir pví sem fólk var fjær offitu. Gagnlíkindahlutföllin sem voru há og marktæk í einfaldasta líkaninu lækkuðu hins vegar og misstu alla marktækni eftir pví sem fleiri skýribreytum var bætt inn í. Ekki er pví hægt að fullyrða að mismunandi líkamspyngdarstuðull fólks hafi marktækt forspárgildi um afstöðu fólks til hlutfallslegrar stöðu heilsu. BMI gat ekki útskýrt neitt annað líkindasamband í peim páttum heilsu sem spurt var um.

Niðurstöðurnar í heild sinni eru að heilsa var almennt talin mjög algild og voru einstaklingar ekki viljugir til pess að fórna heilsu til pess að öðlast hlutfallslega betri heilsu en aðrir. Einnig voru fæstir pættir heilsu aðgreinanlegir hver frá öðrum er varðar hlutfallslega eiginleika. Margir pættir heilsu voru hins vegar undir áhrifum ólíkra breyta, hvort sem eru lýðfræðilegar eða heilsutengdar, sem gátu útskýrt auknar líkur á að einstaklingar meti hlutfallslega stöðu heilsu mikilvægari en algilda. 


\section{STJÓRNSÝSLA}

\section{Umræða}

Niðurstöður könnunarinnar bentu til að allir pættir heilsu séu metnir pannig að fólk kýs síður hlutfallslega sterkari stöðu á kostnað algildrar heilsu. Einnig má vart á milli sjá hvort einhverju munar á ólíkum páttum heilsu. Samkvæmt niðurstöðunum mætti segja að fólk sé fremur reiðubúið að búa við góða heilsu, jafnvel pótt hún sé ekki eins góð og heilsa annarra, heldur en að hafa hlutfallslega betri stöðu en búa pá við síðri heilsu. Niðurstöðurnar í heild sinni eru í takt við pær sem fengust úr rannsóknum Solnick og Hemenway (2005) og Frank og Sunstein (2001) par sem heilsa mældist mjög algild. Hins vegar var fyrirfram búið að geta sér pess til að marktækur munur gæti verið á milli mismunandi vídda heilsu, til dæmis að hreyfanleiki væri hlutfallslegri heldur en verkir og ópægindi, en svo reyndist ekki vera. Afstaða fólks til tekna skiptir peim nánast í tvennt, par sem tæpur helmingur kaus fremur að hafa helmingi minni kaupmátt en aðrir svo lengi sem tekjur peirra eru tvöfalt hærri en tekjur annarra. Er pað í ágætu samræmi við niðurstöður úr vestrænum samfélögum (Solnick og Hemenway 1998, 2005; Alpizar o.fl. 2005; Carlsson o.fl. 2007). Má álykta út frá pví að úrtakið virðist ekki vera frábrugðið, hvað hlutfallslegar tekjur varðar, öðrum úrtökum í sambærilegum rannsóknum. Par var jafnframt áhugaverður munur á milli kynja en konur voru tæplega tvöfalt líklegri til pess að velja hlutfallslegan kost tekna og virðist peim frekar vera hugað um tekjur sínar í samanburði við aðra og kjósa lægri tekjur til pess að fá hlutfallslega betri stöðu.

Geta fólks til að sinna venjubundnum athöfnum er metin í meiri mæli hlutfallsleg en algild af barnlausum, eldri konum. Mætti draga pá ályktun að ungir einstaklingar sem purfa að hugsa um börn vilji síður fórna eigin getu til venjubundinna athafna par sem pað myndi samtímis skerða getu peirra til að sjá um börnin. Líkamlegir verkir og ópægindi eru metin mjög algild en fólk vill purfa að pjást sem minnst jafnvel pótt pað sé meira heldur en aðrir í samfélaginu. Hlutfallslega betri staða virðist ekki fýsileg nema hjá litlu broti svarenda. Einstaklingurinn fær tæplega nytjar í miðjum sársauka pótt hann sé var við að aðrir pjáist enn meira í kringum hann. Aldur hafði hins vegar sterk tengsl við tilhneigingu fólks til að svara hlutfallslegum valkosti verkja og ópæginda, en svo virðist sem að ungt fólk kjósi að upplifa sem minnst af sársauka og ópægindum en hið eldra er frekar reiðubúið að upplifa meiri ef pað skilar sér í hlutfallslega betri stöðu en aðrir í samfélaginu.

Pyngd var sá páttur heilsu sem hvað flestir svöruðu hlutfallslega. Ungt, barnlaust fólk með maka sem metur líkamlega heilsu sína góða eða mjög góða er par líklegast til að velja hlutfallslega kostinn. Reiknað hafði verið með hærra hlutfalli en raunin varð, par sem holdafar er mjög áberandi eiginleiki heilsu og nátengd vestrænum hugmyndum um fegurð, sem hefur verið metin mjög hlutfallsleg í fyrri rannsóknum, eins og Solnick og Hemenway (1998). Niðurstöðurnar eru í samræmi við niðurstöður peirra, að pví leyti að hlutfallsleg fegurð skipti meira máli hjá yngra fólki, en pau drógu pá ályktun að pað gæti verið vegna pess að pað væri síður með maka, án pess pó að hafa upplýsingar um hjúskaparstöðu svarenda. Pegar litið er til hjúskaparstöðu í fjölbreytulíkani pessarar rannsóknar pá er ekkert sem styður pá ályktun. Dvert á móti eru einhleypir marktækt mun ólíklegri en aðrir til pess að velja hlutfallslegan valmöguleika líkamspyngdar. Hugsanlega 
er orðalag spurningarinnar, sem sett er fram pannig að litið er á pyngd sem ógæði, pannig að svörin verða algildari fyrir vikið. Mögulega hefði niðurstaðan verið önnur ef orðalagið væri fremur að pyngd væri gæði, eins og: að vera grannur.

Sú spurning sem oftast var svarað á hlutfallslegan máta varðaði tíðni ungbarnadauða í samfélagi viðkomandi, par sem margir kusu að hafa lægri tíðni en annars staðar, fremur en að hafa enn lægri tíðni en hún væri jafnframt hærri en í öðrum samfélögum. Útkoman er í samræmi við niðurstöður Solnick og Hemenway (2005) sem fengu samskonar svörun við spurningunni. Engin lýðfræðileg eða heilsufarsleg breyta gat skýrt ólíka svörun, en gagnlíkindahlutfallið vék í flestum tilfellum lítið frá 1,0.

Engir lýðfræðilegir eiginleikar gátu útskýrt auknar líkur á að velja annan hvorn valmöguleika um frjósemi en hins vegar kom í ljós að sjálfmetin andleg heilsa hafði sterk neikvæð tengsl við líkur á að velja hlutfallslegan kost frjósemi. Gagnlíkindahlutfallið var 0,25 en ekkert annað samband hafði svo lágt hlutfall. Að pessu gefnu eru peir sem meta andlega heilsu sína sem mjög góða eða góða mun ólíklegri til pess að velja hlutfallslega sterkari stöðu frjósemi, heldur en peir sem meta hana sem sæmilega eða lélega.

Hvað aðra pætti heilsu varðar pá kjósa lang flestir að vera sjaldan veikir, geta sinnt sjálfsumönnun og hafa háar lífslíkur jafnvel pó svo aðrir búi við betri heilsu en peir á peim sviðum. Engar lýðfræðilegar breytur útskýrðu auknar líkur á að velja annan hvorn valmöguleikann í peim spurningum.

Líkamleg og andleg heilsa virðast standa í ólíkum tengslum við hlutfallslega afstöðu til heilsu. Pannig eru peir sem meta líkamlega heilsu sína góða mun líklegri til að svara hlutfallslega á meðan peir sem meta andlega heilsu sína góða eru ólíklegri til að svara hlutfallslega. Dessu mætti líka snúa við og segja að peir sem meti andlega heilsu sína sem sæmilega eða lélega séu að öllu jöfnu líklegri til pess að svara hlutfallslega valmöguleikanum. Dá hefur líkamspyngdarstuðull, BMI, engan marktækan skýringarmátt á mismunandi pætti heilsu, hvort sem notuð er samfelld eða strjál breyta. Við einfalt líkan virtust peir sem flokkaðir eru fjær of feitum vera líklegastir til pess að velja hlutfallslegan kost pyngdar, en sambandið og marktæknin veiktust pegar líkanið var útvíkkað og leiðrétt var fyrir fleiri skýribreytum.

Að framan var minnst á að opinbert framboð á heilbrigðispjónustu leiði mögulega af sér að heilsa verði frekar metin algild, par sem allir eiga greiðan aðgang að heilbrigðispjónustu og möguleika á góðri heilsu. Í kjölfarið var rætt um afar mismunandi útkomu á hlutfallslegum eiginleikum á milli landa og menningarhópa. Hugsanlegt er, að á einum stað par sem aðgengi að heilbrigðispjónustu er öllum opið og fólk almennt við góða heilsu að heilsa sé frekar metin algild, heldur en á öðrum stað par sem heilbrigðiskerfið er ófullkomið og aðgengi dræmt, að heilsa sé par hlutfallslegri. petta er kjörið rannsóknarefni ef lagðar eru svipaðar spurningar fyrir í ólíkum löndum til að varpa frekara ljósi á hlutfallslega eiginleika heilsu.

Erfitt er að fá heilbrigt fólk til pess að setja sig í spor peirra með skerta heilsu og biðja um að hugleiða pann kost að búa við lakari heilsu til pess eins að vera hlutfallslega betur statt en aðrir. Pekkt er að peir sem eru heilsuhraustir ofmeti pá lífsgæðaskerðingu sem fólk með skerta heilsu upplifir, samkvæmt Loewenstein og Schkade (1999), sem 


\section{STJÓRNSÝSLA}

getur verið ein ástæða pess hve algilt mat heilsu er. Raunin virðist aftur á móti vera sú að fólk með skerta heilsu aðlagast vel takmörkunum sem heilsan setur peim, eins og Riis o.fl. (2002) komust að. Рað á pó ekki við um alla pætti heilsu en Frederick og Loewenstein (1999) sýndu að fólk getur illa aðlagast langvarandi sársauka eða geðsjúkdómi. Niðurstaðan er prátt fyrir allt sú að ef fólk er beðið að taka afstöðu til heilsu sinnar í fræðilegum spurningum pá virðist pað í langflestum tilfellum velja að búa við sem bestu heilsu, óháð pví hvernig heilsu pað býr við í raun.

Ýmsir annmarkar eru á rannsóknarsniðinu sem unnið er út frá. Rannsóknin felur í sér einungis fræðilegar spurningar, en ekki er hægt að fylgjast með raunverulegri hegðun fólks og pví er erfitt að rannsaka nákvæmlega hvernig fólk lítur á stöðu sína í samfélaginu. Einstaklingar bregðast mismunandi við ólíkum möguleikum par sem venjur og persónuleiki svarenda hafa áhrif og einnig ef möguleikar eru orðaðir á ólíkan hátt, eins og Tversky og Kahnemann (1981) komust að. Í ritgerð sinni sýndu peir fram á að val einstaklinga getur snúist við, og pá einkum ef spurt er um peninga eða líf og dauða fólks. Er par um að kenna ófullkominni skynjun einstaklinga, par sem annað sjónarhorn á vandamálið breytir hugsanlega miklu um ákvarðanir peirra. Pví er ljóst að með breyttu orðalagi má hafa afgerandi áhrif á niðurstöður og er mögulegt er að svarendur pessarar rannsóknar hafi ekki hugsað svörin að fullu eins og spurningarnar voru settar fram. Einnig eru líkur á að svör fólks litist af viðhorfum og væntingum samfélagsins, pannig að svörun sé hneigð að algilda valkostinum, par sem allir hafa pað betra, jafnvel pótt könnunin sé ópersónugreinanleg. Einstaklingar kjósi pá fremur pann valkost sem aðrir vilja að peir velji. Kallast petta samfélagspóknunar-bjögun (e. social desirability response bias) og einkennist af pví að jákvæðri hegðun er svarað frekar en raunin er, á meðan neikvæðri hegðun er síður svarað (Crowne og Marlowe 1960, Mortel 2008). Bjagar petta niðurstöður rannsókna pannig að einstaklingar koma frekar út sem samfélagslega viðurkenndir. Engu að síður geta niðurstöðurnar gefið gagnlegar upplýsingar, par sem pátttakendur hafa enga sérstaka ástæou til pess að dylja sína raunverulegu skoðun á möguleikunum. Jafnframt er óvissupáttur hver viðmiðunarhópur hvers einstaklings er hverju sinni. Í könnuninni var talað um „aðra“ í samfélaginu. Hvort pessir aðrir séu í nærsamfélagi eins og fjölskyldu, vinnustað, nágrenni eða íbúar í sama bæjarfélagi er ekki vitað. Vel er hugsanlegt að svörin breytist eftir pví hver viðmiðunarhópurinn er og veldur pað óvissu um niðurstöður en mögulega má túlka pær sem einhverskonar meðaltal af öðrum í samfélaginu. Hægt væri að framkvæma rannsókn par sem aðrir í samfélaginu séu skilgreindir með nákvæmari hætti og pá er mögulegt að finna nánar hversu hlutfallslegt fólk er í samanburði við ólíka hópa í samfélaginu. Pá var úrtakið fengið úr nemendum við Háskóla Íslands en ekki tilviljanakennt úrtak úr býði, en pað gæti valdið bjögun á niðurstöðum. Hins vegar hafa flestar atferlisrannsóknir í hagfræði verið úr slíku úrtaki, eins og Solnick og Hemenway (1998), Johansson-Stenman o.fl. (2002) og Alpizar o.fl. (2005). Fyrsta rannsóknin á pessu rannsóknarsviði sem tók almennilegt úrtak úr pýði var Carlsson o.fl. (2007) en niðurstöður peirra voru sambærilegar peim sem beitt höfðu sömu aðferðum og gert er í pessari rannsókn. Lágt svarhlutfall við spurningarlistanum, par sem 419 af 7446 svöruðu, veldur vangaveltum um hvort pað skekki niðurstöður en 
svarendur eru mögulega ólíkir peim sem svöruðu ekki. Niðurstöður gætu hafa orðið aðrar ef betra úrtak hefði verið valið eða spurningarnar orðaðar á annan hátt. Úrtakið samanstóð af ungu fólki í háskólanámi sem var að miklum meirihluta konur og er pví mögulega frábrugðið hefðbundnum pverskurði pjóðfélagsins hvað afstöðu pess varðar til hlutfallslegrar heilsu. Hins vegar er erfitt að sjá hvort og pá hvernig bjagaða úrtakið hefur áhrif á niðurstöður.

Niðurstöður rannsóknarinnar eru í takt við aðrar fyrri rannsóknir. Fólk er fremur reiðubúið að búa við góða heilsu, jafnvel pótt hún sé ekki eins góð og heilsa annarra, heldur en að hafa hlutfallslega betri stöðu en búa pá við síðri heilsu. Pá er ekki að sjá marktækan mun á milli ólíkra pátta heilsu. Að teknu tilliti til lýðfræðilegra pátta kom í ljós að ákveðnir hópar eru líklegri en aðrir til að meta ólíkar víddir heilsu hlutfallslega, eins og getu til að sinna venjubundnum athöfnum og líkamspyngd. Einnig kom í ljós að sjálfmetin líkamleg og andleg heilsa virðist standa í ólíkum tengslum við hlutfallslega afstöðu til heilsu. Drátt fyrir margvíslega annmarka rannsóknarinnar hafa niðurstöðurnar vísindalega pýðingu fyrir viðfangsefnið, en mikilvægt er að halda áfram rannsóknum á hlutfallslegum gæðum atferlishagfræðinnar fyrir ört vaxandi pekkingargrunn á pessu sviði.

\section{Heimildir}

Abel, A. (1990). „Asset Prices under Habit Formation and Catching up with the Joneses“, American Economic Review 80(2): 38-42.

Akay, A., Martinsson, P. og Medhin, H. (2012). „Does Postional Concern Matter in Poor Societies? Evidence from a Survey Experiment in Rural Ethiopia“, World Development 40(2): 428-435.

Alpizar, F., Carlsson, F. og Johansson-Stenman, O. (2005). „How much do we care about absolute versus relative income and consumption?", Journal of Economic Behavior \& Organization 56(3): 405-421.

Arrow, K., Dasgupta, P., Goulder, L., Daily, G., Ehrlich, P., Heal, G., Levin, S., Mäler, K., Schneider, S., Starrett, D. og Walker, B. (2004). „Are we consuming too much?“", Journal of Economic Perspectives 18(3): 147-172.

Berkson, J. (1951). , Why I Prefer Logits to Probits“, Biometrics 9: 357-365.

Carlsson, F., Johansson-Stenman, O. og Martinsson, P. (2007). „Do You Enjoy Having More than Others? Survey Evidence of Positional Goods“, Economica 74(296): 586-598.

Caporale, G., Georgellis, Y., Tsitsianis, N. og Yin, Y. (2009). „Income and happiness across Europe: Do reference values matter?", Journal of Economic Psychology 30(1): 42-51.

Charles, K., Hurst, E. og Roussanov, N. (2009). „Conspicuous consumption and race“, Quarterly Journal of Economics 124(2): 425-467.

Clark, A., Frijters, P. og Shields, M. (2008). „Relative Income, Happiness and Utility: An Explanation for the Easterlin Paradox and Other Puzzles“, Journal of Economic Literature 46(1): 95-144.

Corazzini, L., Esposito, L. og Majorano, F. (2012). „Reign in hell or serve in heaven? A cross-country journey into the relative vs absolute perceptions of wellbeing", Journal of Economic Behavior \& Organization 81(3): 715-730.

Crowne, D. og Marlowe, D. (1960). „A new scale of social desirability independent of pshychopathology". Journal of Consulting Psychology 24: 349-354.

Duesenberry, J. (1949). Income, Saving, and the Theory of Consumer Behavior. Cambridge: Harvard University Press.

Elster, J. (1991). „Envy in social life“, í R. Zeckhauser (ritstj.), Strategy and Choice (bls. 49-82). Cambridge: MIT Press. EuroQol Group. (2011). „EQ-5D-5L User Guide, útgáfa 1,0.“ Sótt 12. júní 2011 á http:// 


\section{STJÓRNSÝSLA}

www.euroqol.org/fileadmin/user_upload/Documenten/PDF/Folders_Flyers/UserGuide_EQ-5D-5L.pdf.

Frank, R. (1985). Choosing the Right Pond. New York: Oxford University Press.

Frank, R. (1991). ,Positional Externalities“, í R. Zeckhauser (ritstj.), Strategy and Choice (bls. 25-47). Cambridge: MIT Press.

Frank, R. (2008). „Should Public Policy Respond to Positional Externalities?““, Journal of Public Economics 92(8-9): 1777-1786.

Frank, R. og Sunstein, C. (2001). „Cost-Benefit Analysis and Relative Position“, University of Chicago Law Review 68(2): 323-374.

Frederick, S. og Loewenstein, G. (1999). „Hedonic adaptation“, í D. Kahneman, E. Diener og N. Schwarz (ritstj.), Well-Being: The Foundations of Hedonic Psychology (bls. 302-329). New York: Russell Sage Foundation.

Frey, B. og Stutzer, A. (2002). „What can economists learn from happiness research?“, Journal of Economic Literature 40(2): 402-435.

Galbraith, J. (1958). The Affluent Society. Boston: Houghton Mifflin.

Hirsch, F. (1976). Social Limits to Growth. Cambridge: Harvard University Press.

Hirschman, A. og Rothschild, M. (1973). „The changing tolerance for income inequality in the course of economic development", Quarterly Journal of Economics 87(4): 544-566.

Hopkins, E. og Kornienko, T. (2009). „Status, affluence and inequality: Rank-based comparisons in games of status“, Games and Economic Behavior 67(2): 552-568.

Johansson-Stenman, O., Carlsson, F. og Daruvala, D. (2002). „Measuring future grandparents‘ preferences for equality and relative standing“" Economic Journal 112(479): 362-383.

Knight, J., Song, L. og Gunatilaka, R. (2009). „Subjective well-being and its determinants in rural China“, China Economic Review 20(4): 635-649.

Layard, R. (2011). Happiness: Lessons from a new science. London: Penguin Books.

Loewenstein, G. og Schkade, D. (1999). „Wouldn't it be nice? Predicting future feelings“ í D. Kahneman, E. Diener og N. Schwarz (ritstj.). Well-Being: The Foundations of Hedonic Psychology (bls. 85-105). New York: Russell Sage Foundation.

van de Mortel, T.F. (2008). „Faking it: social desirability response bias in self-report research“, Australian Journal of Advanced Nursing 25(4): 40-48.

Mehra, R. og Prescott, E. (1985). „The Equity Premium: A Puzzle“, Journal of Monetary Economics 15(2): 145-161.

Riis, J., Loewenstein, G., Baron, J., Jepson, C., Fagarlin, A. og Ubel, P. (2005). „Ignorance of hedonic adaptation to hemo-dialysis", Journal of Experimental Psychology 134(1): 3-9.

Smith, A. (1776). An Inquiry into the Nature and Causes of the Wealth of Nations. Endurútgefið: R. Campbell og A. Skinner (ritstj.). Indianapolis: Liberty Classics, 1981.

Solnick, S. og Hemenway, D. (1998). „Is more always better?: Asurvey on positional concerns“, Journal of Economic Behavior \& Organization 37(3): 373-383.

Solnick, S. og Hemenway, D. (2005). „Are Positional Concerns Stronger in Some Domains than in Others?" "The American Economic Review, 95(2): 147-151.

Solnick, S., Hong, Li, Hemenway, D. (2007). „Positional goods in the United States and China“, The Journal of Socio-Economics 36(4): 537-545.

Tervala, J. (2012). „Keeping up with the Joneses and the welfare effects of monetary policy“, Journal of Economic Psychology 33(1): 104-111.

Tversky, A. og Griffin, D. (1991). „Endowment and contrast in judgments of well-being“, í R. Zeckhauser (ritstj.), Strategy and Choice (bls. 297-319). Cambridge: MIT Press.

Tversky, A. og Kahnemann, D. (1981). „The Framing of Decisions and the Psychology of Choice“, Science 211(4481): 453-458.

Veblen, T. (1889). The Theory of the Leisure Class. New York: MacMillan. 
Veenhoven, R. (1993). Happiness in Nations: Subjective appreciation of life in 56 nations 1946-1992. Rotterdam Erasmus University.

World Health Organization. (2005) „The World Health Report 2005. Make every mother and child count.“ WHO Press.

World Health Organization. (e.d.). „The International Classification of adult underweight, overweight and obesity according to BMI.“ Sótt 21. júlí 2012 á http://apps.who.int/bmi/index.jsp?introPage=intro_3.html 
STJÓRNSÝSLA 